\title{
HUBUNGAN KOMPETENSI PROFESIONAL WIDYAISWARA DAN PRESTASI BELAJAR GURU TERHADAP HASIL UJI SERTIFIKASI KOMPETENSI GURU KEAHLIAN GANDA
}

\section{Titin Karnasih, Sitti Nursetiawati dan Mahdiyah}

Universitas Negeri Jakarta (UNJ)

Email: titinkarnasih278@gmai.com,soeminotinuk@gmail.com dan mahdiyah.unj@gmail.com

\begin{abstract}
Research using a quantitative approach with ex post facto method aims to bring up the hypothesis that there is a relationship between widyaiswara professional competence and the learning achievements of PKG training participants with the results of multiple expertise competency certification. Samples taken were 8 widyaiswara Presenters of Training Materials for Hair and Face Beauty Package, 43 participants (teachers) Training in Hair and Facial Beauty Skills Packages. Data analysis was performed on the data obtained using associative parametric statistical inferential techniques (relationship) to the research variables using Chisquare. The results of the calculation show that there is no relationship between widyaiswara professional competence and the learning achievement of PKG training participants with the results of multiple expertise competency certification. This indicates that the results of multiple expertise competency certifications are determined from other matters outside of Widyaiswara's professional competencies and the learning achievements of PKG training participants.
\end{abstract}

Keywords: Professional lecturer competence, teacher learning achievement, skill competency certification test result

\begin{abstract}
Abstrak
Penelitian ini menggunakan pendekatan kuantitatif dengan metode ex post facto bertujuan memunculkan hipotesis adanya hubungan kompetensi professional widyaiswara dan prestasi belajar peserta diklat PKG dengan hasil sertifikasi kompetensi keahlian ganda. Sampel yang diambil adalah 8 widyaiswara Penyaji Materi Pelatihan Paket Keahlian Kecantikan Rambut dan Wajah, 43 peserta (guru) Pelatihan Paket Keahlian Kecantikan Rambut dan Wajah. Analisa data dilakukan terhadap data yang diperoleh menggunakan teknik analis statistik inferensial parametris asosiatif (hubungan) terhadap variable penelitian menggunakan Chisquare. Hasil perhitungan menunjukkan tidak ada hubungan antara kompetensi professional widyaiswara dan prestasi belajar peserta diklat PKG dengan hasil sertifikasi kompetensi keahlian ganda. Hal tersebut mengindikasikan bahwa hasil sertifikasi kompetensi keahlian ganda ditentukan dari hal-hal lain di luar kompetensi professional widyaiswara dan prestasi belajar peserta diklat PKG.
\end{abstract}


Kata kunci: Kompetensi Profesional Widyaiswara, Prestasi Belajar Guru , Hasil Uji Sertifikasi Kompetensi Keahlian

\section{Pendahuluan}

Indonesia terus mendorong meningkatnya indeks Human Development Index (HDI) atau Indek Pembangunan Manusia (IPM) Indonesia dimata internasional melalui peningkatan mutu pendidikan. Pendidikan sangat penting dan menduduki posisi sentral dalam pembangunan karena berorientasi pada peningkatan mutu sumber daya manusia (Anggara, 2017). Pada jalur pendidikan di Sekolah Menengah Kejuruan (SMK) terutama dilakukan dengan meningkatkan standar lulusan. Berdasarkan data dari Pusat Data dan Statistik Pendidikan dan kebudayaan (2016: 48) diketahui jumlah lulusan SMK tahun 2016 adalah 1.285.178. Dengan jumlah tersebut akan menjadi masalah besar jika tidak dapat memenuhi tujuan pelaksanaannya. Totok Suprayitno (BNSP, 2017: 12) menyatakan, "lulusan SMK/MAK tidak hanya disiapkan secara khusus untuk memenuhi keterampilan bekerja (job specific skills), tetapi juga harus dibekali dengan keterampilan belajar (learning skills) dan kemampuan menyesuaikan diri atau adaptability competence.

Untuk memenuhinya, penerapan pembelajaran di SMK memiliki ciri berbasis kompetensi dan berbasis produksi. Hal tersebut mengindikasikasikan jika "Pengalaman belajar yang diberikan di SMK telah menerapkan pendekatan Competency Based Training dan Product Based Training yang disesuaikan dengan bidang keahlian yang dikembangkan, sehingga akan berimplikasi pada penilaian hasil belajar atau pengujian kompetensi peserta didik" (Jubaedah, 2012). Grafaloka, G., Lukaova, J., dan Bugelova (2011) dalam (Rizkiyah, Mariana, \& Soekopitojo, 2018) menyatakan, "Peranan guru memberikan dampak besar pada pengembangan pengetahuan dengan kemampuan untuk mentransfer hasil ilmu ke siswa sedemikian rupa untuk mereka pahami."

Sedangkan berdasarkan data Kemendikbud seperti dimuat dalam Kompas.com (5 Mei 2018) diketahui "kekurangan jumlah guru produktif disemua program keahlian pada tahun 2016 adalah sejumlah 235.269 orang." Untuk mengatasi masalah tersebut Kemendikbud melaksanakan Program Keahlian Ganda (PKG). PKG dalam bidang Pariwisata yakni Tata Kecantikan dengan Kompetensi Tata Kecantikan Wajah dan Rambut dilaksanakan oleh Unit Lembaga Pelaksana Program dari Pusat Pengembangan dan Pemberdayaan Pendidik dan Tenaga Kependidikan (PPPPTK) Bisnis dan Pariwisata (P4TK Bispar). Kurikulum Kompetensi Keahlian Kecantikan yang digunakan adalah Standar Kompetensi Guru dan SKKNI Tata kecantikan Wajah dan Rambut dengan bahan ajar digunakan berdasarkan pada paket keahlian yang dituangkan dalam 10 modul. Penilaian guru peserta PKG adalah menggunakan penilaian Kompetensi Kerja dengan melihat sikap, pengetahuan, keterampilan dan atau keahlian serta penerapannya secara effektif dalam pekerjaan yang dilakukan sesuai dengan standar kerja yang dipersyaratkan. Standar kerja ini menggunakan Skema Sertifikasi KKNI level IV pada kompetensi keahlian yang dipersyaratkan. Sehingga, pencapaian standar minimal harus dapat dikuasai sebelum guru tersebut mengajar pada bidang 
keahlian produktif. "Diperlukan dukungan dari guru-guru profesional dan berkompeten yang mampu membantu memfasilitasi, mencetak generasi yang cerdas, unggul dan berakhlak mulia" (Hadian \& Yulianti, 2011).

Kegiatan pendidikan dan pelatihan pada PPPPTK pada pelaksanaannya dilakukan oleh widyaiswara. Widyaiswara menurut PERMENPAN No. 14 Tahun 2009 merupakan jabatan fungsional yang mempunyai ruang lingkup, tugas, tanggung jawab, dan wewenang untuk mendidik, mengajar dan/atau melatih PNS pada lembaga diklat pemerintah."Widyaiswara yang kompeten akan lebih mampu membawa dan menciptakan lingkungan belajar yang kondusif dan efektif serta akan lebih mampu mengelola kelasnya dan membawa peserta diklat pada pencapaian hasil belajar yang optimal" (Triastuty, Purnama, \& Sumpeno, n.d.).

Sebagai bagian dari elemen diklat, maka kesuksesan suatu program pengajaran diklat juga ditentukan oleh profesionalisme yang dimiliki oleh widyaiswara. Widyaiswara yang profesional akan memiliki kompetensi atau kemampuan mengajar dan kemampuan memfasilitasi yang unggul dalam suatu proses pembelajaran/pelatihan. Spencer dan Spencer (1993), mendefinisikan kompetensi sebagai karakteristik dasar seseorang berkaitan dengan efektivitas kinerja individu dalam pekerjaannya. Dalam rangka mendapatkan widyaiswara yang profesional diperlukan standar kompetensi widyaiswara. Keterampilan-keterampilan yang dimiliki seorang widyaiswara dapat diaplikasikan ke dalam pofesi sebagai berikut: 1). Keterampilan menyampaikan gagasan (speaking skill), 2). Keterampilan berpikir (thingking skill), 3). Keterampilan menjaga hubungan antar pribadi (interpersonal skill), 4). Keterampilan menjalin hubungan kerja (Network skill), 5). Keterampilan mengembangkan diri (Growth), dan 6). Disiplin (Dicipline) (Yasri, bin Hamid, \& Yap, 2009).

Keterampilan-keterampilan tersebut dapat menunjang penyelenggaraan suatu diklat yang effektif dan effesien sehingga dapat mencapai tujuan diklat dan berdampak pada kinerja secara keseluruhan dari peserta diklat. Suatu pembelajaran dikatakan efektif apabila memenuhi persyaratan utama keefektifan pemgajaran, yaitu: 1). Presentasi waktu belajar siswa yang tinggi dicurahkan terhadap KBM, 2). Rata-rata melaksanakan tugas yang tinggi, 3). Ketepatan antara kandungan materi ajaran dengan kemampuan siswa (orientasi keberhasilan belajar) diutamakan, 4). Mengembangkan suasana belajar yang akrab dan positif (Trianto \& Pd, 2007).

Namun demikian, pada penelitian terdahulu masih terdapat beberapa indikator efektifitas pembelajaran yang kurang terpenuhi. "Terdapat sebagian widyaiswara yang kurang kreatif dalam menciptakan atmosfir kelas yang menarik sehingga proses komunikasi tidak optimal dan terdapat widyaiswara yang kurang memperhatikan penggunaan waktu sehingga penyampaian materi tidak terstruktur dengan baik" (Nugraha, 2014). Berdasarkan uraian di atas maka dapat dipastikan jika perlu menjamin mutu widyaiswara untuk dapat menghasilkan widyaiswara profesional yang dapat mendukung mutu guru yang dihasilkan dari proses diklat. Untuk itu widyaiswara harus memiliki kompetensi dalam melaksanakan tugasnya untuk menjadi tenaga pendidik dan pelatihan sehingga guru-guru normatif dan adaptif tersebut dapat memiliki kompetensi 
guru produktif Tata Kecantikan. Untuk itu, perlu diketahui adakah hubungan Kompetensi Professional Widyaiswara dan Prestasi Belajar Guru dengan Hasil Uji Sertifikasi Kompetensi Keahlian Ganda Guru?.

\section{Metode Penelitian}

Metode penelitian ex post facto dengan pendekatan penelitian kuantitatif dengan memunculkan memunculkan dugaan (hipotesis) adanya hubungan antar variabel dalam populasi yang diuji. Dari kelompok widyaiswara sampel yang diambil adalah berjumlah 8 widyaiswara Penyaji Materi Pelatihan Paket Keahlian Kecantikan Rambut dan Wajah (P4TK Bispar). Sedangkan dari kelompok guru, sampel yang diambil berjumlah 26 peserta Pelatihan Paket Keahlian Kecantikan Rambut dan 54 peserta Pelatihan Paket Keahlian Kecantikan Wajah.

\section{Variabel Kompetensi Professional Widyaiswara}

Pada penelitian ini evaluasi terhadap kompetensi professional widyaiswara dilakukan dalam 4 tahapan. Pada setiap tahapan dievaluasi kompetensinya sebagai Penyaji Materi Pelatihan dengan 4 kompetensi penilaian yaitu: 1) Pengelolaan pembelajaran (Keterampilan), 2). Sosial, 3). Kepribadian, 4). Substantif.

Tabel 1 Kisi-kisi Instrument Kompetensi Professional Widyaiswara

\begin{tabular}{|c|c|c|c|}
\hline No & Aspek & $\begin{array}{l}\text { Kompetensi } \\
\text { Penilaian }\end{array}$ & Indikator \\
\hline \multirow[t]{13}{*}{1.} & \multirow{13}{*}{$\begin{array}{l}\text { Penyaji } \\
\text { Materi } \\
\text { Pelatihan }\end{array}$} & \multirow[t]{2}{*}{$\begin{array}{l}\text { a. Kompetensi } \\
\text { substantif }\end{array}$} & $\begin{array}{l}\text { 1) Penguasaan dan Pengembangan } \\
\text { Materi }\end{array}$ \\
\hline & & & 2) Pencapaian ujian pembelajaran \\
\hline & & \multirow{3}{*}{$\begin{array}{l}\text { b. Kompetensi } \\
\text { sosial; }\end{array}$} & 1) Penggunaan Bahasa \\
\hline & & & 2) Cara menjawab pertanyaan peserta \\
\hline & & & $\begin{array}{l}\text { 3) Pengawasan terhadap keselamatan } \\
\text { dan kesehatan kerja }\end{array}$ \\
\hline & & \multirow{3}{*}{$\begin{array}{l}\text { c. Kompetensi } \\
\text { kepribadian; }\end{array}$} & 1) Sikap dan perilaku \\
\hline & & & 2) Kerapihan berpakaian \\
\hline & & & 3) Disiplin kehadiran \\
\hline & & \multirow{5}{*}{$\begin{array}{l}\text { d. Kompetensi } \\
\text { pengelolaan } \\
\text { pembelajaran }\end{array}$} & 1) Sistematika penyajian \\
\hline & & & 2) Kemampuan menyajikan \\
\hline & & & $\begin{array}{l}\text { 3) Pemilihan metode } \\
\text { menghidupkan suasana }\end{array}$ \\
\hline & & & $\begin{array}{l}\text { 4) } \begin{array}{l}\text { Penggunaan alat } \\
\text { pembelajaran/alat praktik }\end{array} \\
\end{array}$ \\
\hline & & & $\begin{array}{l}\text { 5) Pemberian motivasi belajar pada } \\
\text { peserta }\end{array}$ \\
\hline
\end{tabular}

Untuk indikator Penguasaan dan Pengembangan Materi, penilaiannya adalah hasil tes tertulis yang diberikan berupa 150 soal pilihan berganda terkait tata kecantikan rambut dan wajah. Sistem penilaian untuk tes pertanyaan pilihan ganda ini adalah dengan memberi nilai 1 jika jawaban benar dan skor nilai 0 jika jawaban 
salah kemudian jumlah niali yang benar dibagi jumlah seluruh soal lalu dikalikan 100.

Pembobotan penilaian kompetensi professional Widyaiswara adalah sebagai berikut:
a. Kompetensi pengelolaan pembelajaran $40 \%$
b. Kompetensi kepribadian $10 \%$
c. Kompetensi sosial $10 \%$
d. Kompetensi substantif $40 \%$

Tabel 2 Skala Penilaian Evaluasi Widyaiswara
\begin{tabular}{cl}
\hline Rentang Nilai & Keterangan \\
\hline$\leq 59$ & $\begin{array}{l}\text { Kurang } \\
\text { Sekali }\end{array}$ \\
\hline $60-69$ & Kurang \\
\hline $70-79$ & Cukup \\
\hline $80-89$ & Baik \\
\hline $90-100$ & Baik Sekali \\
\hline
\end{tabular}

\section{Variabel Prestasi Belajar Peserta Diklat PKG}

Instrumen yang diajukan untuk melihat Prestasi Belajar Peserta Diklat PKG adalah berupa tes tertulis pada evaluasi Aktivitas Kegiatan Pada PKG. Evaluasi tertulis tersebut terdapat pada proses $\mathrm{ON}-1, \mathrm{IN}-1, \mathrm{ON}-2$, IN-2, yang terdiri atas modul A sampai dengan modul J. Adapun setiap modul terdiri dari 20 soal (10 modul $=200$ soal) pilihan ganda dengan indikator: Tahu, Memahami, Penerapan, Analisis, Sintesis dan Evaluasi. Sistem penilaian yang digunakan adalah memberi nilai 1 jika jawaban benar dan skor nilai 0 jika jawaban salah, kemudian jumlah nilai yang benar dibagi jumlah seluruh soal lalu dikalikan 100 .

\section{Variabel Hasil Uji Sertifikasi Kompetensi Keahlian Ganda Guru}

Instrumen yang diajukan untuk melihat Hasil Uji Sertifikasi Kompetensi Keahlian Ganda Guru berupa sertifikat yang dimilikinya, yaitu berupa Sertifikat Pendidik dan Sertifikat Keahlian yang dimilikinya.

\section{Tabel 3 Kisi-Kisi Instrumen Hasil Uji Sertifikasi Kompetensi Keahlian Ganda Guru}

\begin{tabular}{llll}
\hline No & \multicolumn{1}{c}{ Kompetensi } & \multicolumn{2}{c}{ Pilihan Jawaban } \\
\cline { 3 - 3 } & & Ya & Tidak \\
\hline 1. & Sertifikat & & \\
& Pendidik/PLPG & & \\
\hline
\end{tabular}

Pernyataan yang diajukan untuk menjawab kompetensi yang dimilikinya dilakukan dengan memberikan pernyataan dengan menyertakan pilihan jawaban. Untuk dapat menganalisanya secara statistik maka setiap jawaban tersebut memiliki nilai (skor), yaitu: 
Tabel 4 Skala Penilaian Hasil Uji Sertifikasi Kompetensi Keahlian Ganda Guru

\begin{tabular}{lc}
\hline \multicolumn{1}{c}{ Pilihan Jawaban } & Nilai \\
\cline { 2 - 2 } Ya & 1 \\
\hline Tidak & 0 \\
\hline
\end{tabular}

Analisa data dilakukan terhadap data yang diperoleh menggunakan teknik analis statistik inferensial parametris asosiatif (hubungan) menggunakan rumus chisquare.

\section{Hasil dan Pembahasan}

\section{A. Hasil}

\section{Kompetensi Profesional Widyaiswara Dan Hasil Uji Sertifikasi Kompetensi} Keahlian Ganda Guru

Berdasarkan data yang diperoleh peneliti dari 8 orang widyaiswara tata kecantikan tersebut diketahui sebanyak 6 widyaiswara kompetensi profesionalnya masuk dalam kategori Baik (rentang nilai 80 - 89) dan sebanyak 2 widyaiswara kompetensi profesionalnya masuk dalam kategori Baik Sekali (rentang nilai 90 - 100).

Tabel 5 Crosstabulation Kompetensi Profesional Widyaiswara dan Hasil Uji Sertifikasi Kompetensi Keahlian Ganda Guru

\begin{tabular}{lllrrr}
\hline & & \multicolumn{3}{c}{ Hasil_PLPG } & \\
\cline { 3 - 5 } & & Tidak Lulus & Lulus & Total \\
\hline \multirow{2}{*}{ Kompetensi } & Baik & Count & 6 & 26 & 32 \\
\cline { 2 - 5 } & & $\%$ within Hasil PLPG & $75,0 \%$ & $74,3 \%$ & $74,4 \%$ \\
\cline { 2 - 5 } & Baik & Count & 2 & 9 & 11 \\
\cline { 3 - 6 } & Sekali & \% within Hasil PLPG & $25,0 \%$ & $25,7 \%$ & $25,6 \%$ \\
\hline \multirow{2}{*}{ Total } & Count & 8 & 35 & 43 \\
\cline { 2 - 5 } & \% within Hasil PLPG & $100,0 \%$ & $100,0 \%$ & $100,0 \%$ \\
\hline
\end{tabular}

Kemudian dari 43 Peserta Diklat PKG sebanyak 6 tidak lulus dan 32 lulus PLPG dari widyaiswara yang memiliki kompetensi pada tingkat Baik. Pada widyaiswara dengan kompetensi Baik Sekali terdapat 2 Peserta Diklat PKG yang tidak lulus dan 9 yang lulus PLPG. Hasil perhitungan menggunakan chisquare antara Kompetensi professional terhadap Hasil Uji Sertifikasi Kompetensi Keahlian Ganda Guru didapatkan nilai Pearson Chi-Square sebesar 0,002 ${ }^{\mathrm{a}}$ dengan nilai df sebesar 1 pada Asymp. Sig. (2-sided) adalah 1,000 sehingga $>$ 0,005 maka hipotesis alternatif terpenuhi yakni tidak ada hubungan Kompetensi professional terhadap Hasil Uji Sertifikasi Kompetensi Keahlian Ganda Guru. 


\section{Prestasi Belajar Peserta Diklat PKG Dan Hasil Uji Sertifikasi Kompetensi Keahlian Ganda Guru \\ Tabel 6 Crosstabulation Prestasi Belajar Peserta Diklat PKG dan Hasil Uji Sertifikasi Kompetensi Keahlian Ganda Guru}

\begin{tabular}{|c|c|c|c|c|c|}
\hline & \multicolumn{2}{|c|}{ Hasil_PLPG } & \multirow[t]{2}{*}{ Total } \\
\hline & & & Tidak Lulus & Lulus & \\
\hline \multirow[t]{8}{*}{ Prestasi } & \multirow[t]{2}{*}{ Kurang } & Count & 2 & 20 & 22 \\
\hline & & $\%$ within Hasil PLPG & $25,0 \%$ & $57,1 \%$ & $51,2 \%$ \\
\hline & \multirow[t]{2}{*}{ Cukup } & Count & 3 & 5 & 8 \\
\hline & & $\%$ within Hasil PLPG & $37,5 \%$ & $14,3 \%$ & $18,6 \%$ \\
\hline & \multirow[t]{2}{*}{ Baik } & Count & 3 & 6 & 9 \\
\hline & & $\%$ within Hasil PLPG & $37,5 \%$ & $17,1 \%$ & $20,9 \%$ \\
\hline & \multirow{2}{*}{$\begin{array}{l}\text { Baik } \\
\text { Sekali }\end{array}$} & Count & 0 & 4 & 4 \\
\hline & & $\%$ within Hasil PLPG & $0,0 \%$ & $11,4 \%$ & $9,3 \%$ \\
\hline \multirow{2}{*}{\multicolumn{2}{|c|}{ Total }} & Count & 8 & 35 & 43 \\
\hline & & $\%$ within Hasil PLPG & $100,0 \%$ & $100,0 \%$ & $100,0 \%$ \\
\hline
\end{tabular}

Dari data tabulasi di atas yang diperoleh diketahui jika dari 43 Peserta Diklat PKG memiliki tingkatan rentang prestasi belajar Kurang, Cukup, Baik dan Baik Sekali. Dari rentang prestasi belajar Kurang yang dimilkinya diketahui 2 Peserta Diklat PKG tidak lulus dan 20 Peserta Diklat PKG yang lulus PLPG. Lalu dari prestasi belajar Cukup 3 Peserta Diklat PKG tidak lulus dan 5 Peserta Diklat PKG lulus PLPG. Kemudian dari Peserta Diklat PKG yang memiliki prestasi belajar Baik terdapat 3 Peserta Diklat PKG tidak lulus dan 6 Peserta Diklat PKG lulus PLPG, sedangkan dari Peserta Diklat PKG yang memiliki prestasi belajar Baik Sekali tidak terdapat (0) Peserta Diklat PKG tidak lulus dan 4 Peserta Diklat PKG lulus PLPG.

Hasil perhitungan Chi-Square diketahui Prestasi Belajar Peserta Diklat PKG dan Hasil Uji Sertifikasi Kompetensi Keahlian Ganda Guru diketahui nilai Pearson Chi-Square adalah 5,405 ${ }^{\mathrm{a}}$ dengan nilai df sebesar 3 pada Asymp. Sig. (2-sided) adalah 1,000 sehingga > 0,005 maka hipotesis alternatif terpenuhi yakni tidak ada hubungan prestasi belajar terhadap Hasil Uji Sertifikasi Kompetensi Keahlian Ganda Guru.

\section{B. Pembahasan}

Dari hasil penelitian diketahui jika secara statistik tidak ada hubungan Kompetensi Professional Widyaiswara dan Prestasi Belajar (Guru) Peserta Diklat PKG dengan Hasil Uji Sertifikasi Kompetensi Keahlian Ganda Guru. Hal tersebut mengindikasikan jika dugaan hipotesis yang diajukan tidak terbukti secara statistik sehingga dapat diasumsikan bahwa peningkatan Kompetensi Professional Widyaiswara dan Prestasi Belajar (Guru) Peserta Diklat PKG tidak valid untuk mengestimasi Hasil Uji Sertifikasi Kompetensi Keahlian Ganda Guru. Keadaan tersebut berarti terdapat hal-hal lain di luar Kompetensi Professional Widyaiswara dan Prestasi Belajar (Guru) Peserta Diklat PKG yang memiliki hubungan dengan Hasil Uji Sertifikasi Kompetensi Keahlian Ganda Guru. 
Kompetensi Professional Widyaiswara pada penelitian ini diukur dari kemampuannya sebagai Penyaji Materi Pelatihan dengan 4 kompetensi penilaian, yaitu: 1) Pengelolaan pembelajaran (Keterampilan), 2). Sosial, 3). Kepribadian, 4). Substantif. Pelaksanaannya dilakukan oleh Seksi Evaluasi PPPPTK Bisnis dan Pariwisata yang dilakukan dalam 4 tahapan. Dari hasil evaluasi tersebut diketahui sebagian besar $(75 \%)$ widyaiswara memiliki kompetensi professional Baik dan sisanya $(25 \%)$ justru memiliki kompetensi professional yang Baik Sekali. Hasil tersebut mengindikasikan seluruh widyaiswara telah memiliki kompetensi professional yang dibutuhkan dalam menjalankan fungsi, peran, dan tugasnya sebagai pendidik, mengajar dan/atau melatih PNS sesuai dengan materi pelatihan (guru tata kecantikan rambut dan wajah). Namun demikian, kompetensi yang diberikan pada saat diklat PKG tersebut tidak sama/kurang dengan kompetensi yang diharapkan untuk dapat meluluskan diklat PLPG. Pelaksanaan Pendidikan dan Pelatihan Profesi Guru (PLPG) dilakukan guru untuk mendapat sertifikat pendidik sekaligus menjadi bukti formal bahwa guru tersebut telah profesional sebagai guru produktif SMK. Berdasarkan hal tersebut maka kompetensi yang harus dimiliki untuk dapat lulus adalah kompetensi pendidik dan keahlian.

"Terdapat pengaruh positif namun tidak signifikan dari pemahaman atas perencanaan diklat terhadap kualitas penyelenggaraan diklat. Kelayakan penganggaran diklat berpengaruh positif dan signifikan terhadap kualitas penyelenggaraan diklat". Kelayakan penganggaran diklat terkait dengan tersedianya sarana dan prasarana diklat yang bukan saja memadai dari segi jumlah tapi mampu menyediakan sesuai dengan perkembangannya. Kelayakan tersebut dapat berimbas pada penyampaian materi diklat (guru tata kecantikan rambut dan wajah) sesuai dengan perkembangan. Faktor yang mendukung pendidikan dan pelatihan ToT adalah UU Nomor 43 tahun 1999, tentang pokok kepegawaian, PP nomor 101 tahun 2000 tentang pendidikan dan pelatihan pegawai negeri sipil dan kuatnya komitmen Kepala Badan Diklat dan pimpinan vertical pemerintahan provinsi untuk meningkatkan kompetensi pegawai widyaiswara. Sedangkan faktor yang menghambat adalah terbatasnya staf pengajar/widyaiswara yang professional, dan tebatasnya alokasi anggaran pendidikan dan pelatihan.

Kompetensi Widyaiswara selaku fasilitator diklat berdasarkan hasil penelitian (Warisdiono, Gani, \& Susanto, 2013) dipengaruhi secara signifikan oleh faktor-faktor keterlibatan fasilitator dalam proses belajar, motivasi, dan lingkungan kerja. Sementara itu karakteristik individu tidak berpengaruh signifikan terhadap kompetensi fasilitator. Untuk mewujudkan widyaiswara yang professional, selama ini difokuskan dengan meningkatkan frekuensi pelatihan namun harus memperhatikan kebutuhan pengetahuan, keterampilan widyaiswara. Selain mengikuti pelatihan, proses belajar widyaiswara tersebut juga dapat dilakukan dengan berpartisipasi dalam kegiatan-kegiatan ilmiah, mengikuti magang industri, dan pemanfaatan sumber belajar yang ada. Perbaikan lingkungan kerja widyaiswara dapat dilakukan dengan pemberian penghargaan, sistem evaluasi, ketersediaan 
sarana dan prasarana, sistem pengembangan karir, dan sistem pelaksanaan kegiatan pelatihan. Dalam hal evaluasi tentu akan lebih objektif jika evaluasi widyaiswara juga dilakukan oleh pihak lain di luar P4TK, penilaianya bukan hanya terkait materi-materi yang akan diajarkannya tapi juga menilai motivasi diri widyaiswara. Motivasi tersebut penting menginagt motivasi adalah sesuatu dari dalam diri yang menggerakkan atau mendorong untuk melaksanakan tugasnya, seperti memperluas hubungan kerja, mengembangkan kemampuan bidang ilmu, dan melaksanakan tugas pembelajaran.

"Komponen penilaian diyakini memberikan dampak nyata bagi keberhasilan pembelajaran kompetensi kepada siswa, maka penilaian kini ditempatkan pada posisi yang penting dalam rangkaian kegiatan pembelajaran. Bentuk dan cara penilaian dalam banyak hal memberikan pengaruh penting bagi proses pembelajara..." (Nurgiyantoro, 2008: 250-251).

Prestasi belajar peserta Diklat PKG gelombang 1 dan 2 didasarkan pada hasil/nilai rata-rata evaluasi tertulis pada modul A sampai J peserta Diklat PKG. Jika dilihat dari hasil perhitungan diketahui prestasi belajar yang dimiliki peserta menyebar dari tingkatan Kurang (60 - 69) hingga tingkatan Baik Sekali (90 - 100). Berdasarkan hal tersebut maka prestasi belajar dari evaluasi tertulis harus ditingkatkan sehingga tidak ada prestasi belajar yang berada dalam tingkatan kurang. Hasil tersebut juga memperlihatkan dari seluruh peserta Diklat PKG jumlah peserta dengan prestasi belajar tingkat Kurang adalah yang terbanyak (20 peserta $=$ $57,1 \%$ ) mendapatkan sertifikat PLPG (lulus) sedangkan yang paling sedikit (4 peserta $=11,4 \%$ ) mendapatkan sertifikat PLPG (lulus) adalah peserta Diklat PKG dengan prestasi belajar baik. Berdasarkan uraian tersebut jelas terlihat jika prestasi belajar peserta Diklat PKG tidak memiliki hubungan terhadap Hasil Uji Sertifikasi Kompetensi Keahlian Ganda Guru, sehingga peningkatan prestasi belajar peserta Diklat PKG (evaluasi tertulis) bukanlah yang menentukan keberhasilan guru lulus PLPG. Hal ini terjadi prestasi belajar pada penelitian ini hanya dilihat dari nilai rata evaluasi tertulis pada modul diklat A sampai dengan $\mathrm{J}$ sedangkan dasar penilaian kelulusan PLPG adalah kompetensi pendidik dan keahlian, sehingga apa yang diajarkan pada kegiatan PKG perlu memperhatikan pula kompetensi-kompetensi yang diperlukan untuk menjadi guru SMK professional. “...kurangnya keterampilan dari para guru untuk mengajar mata pelajaran produktif yang diampu" (Ananda, Mukhadis, \& Andoko, 2012).

Widyaiswara secara umum bertanggung jawab atas terselenggaranya pembinaan dan pengembangan yang efektif dan akuntabel melalui Diklat yang berkualitas sehingga diharapkan dapat memberikan dampak terhadap prestasi belajar dari para peserta Diklat PKG. Namun demikian, dalam mencapai prestasi belajar yang maksimal tentu perlu diperhatikan seluruh komponen dalam kegiatan pembelajaran termasuk adalah peserta didik itu sendiri. "Peningkatan mutu pendidikan, menyangkut pengendalian komponen-komponen pendidikan yang menunjang terpenuhinya mutu pendidikan yang dibutuhkan dunia kerja. 
Komponen-komponen tersebut terdiri atas kebijakan mutu pendidikan, kurikulum, pembelajaran, fasilitas pendidikan, peserta didik, dan pendidik" (Ratnata, Saputra, Somantri, Mulyana, \& Ardhika, 2018).

Sesuai dengan Buletin Fokus/Edisi VII/November 2016, sasaran Program Keahlian Ganda (PKG) adalah: 1). Guru SMA mata pelajaran: PPKn, Biologi, Fisika, Kimia, Geografi, Ekonomi, Bahasa Asing Lain, Antropologi; 2). Guru Adaptif \& Normatif SMK; dan 3). Guru SMA dan SMK Dampak K-13: TIK, IPA, IPS, Kewirausahaan (Redaksi, n.d.).

Berdasarkan hal tersebut perlu pertimbangan lain terkat dengan sasaran Program Keahlian Ganda (PKG) yang telah ditetapkan sehingga keberhasilan program lebih dapat dimaksimalkan, terutama untuk menghasilkan guru SMK yang professional.

\section{Kesimpulan}

1. Tidak ada hubungan Kompetensi Professional Widyaiswara dengan Hasil Uji Sertifikasi Kompetensi Keahlian Ganda Guru

2. Tidak ada hubungan Kompetensi Professional Widyaiswara dengan Hasil Uji Sertifikasi Kompetensi Keahlian Ganda Guru

3. Tidak ada hubungan Kompetensi Professional Widyaiswara dan Prestasi Belajar (Guru) Peserta Diklat PKG dengan Hasil Uji Sertifikasi Kompetensi Keahlian Ganda Guru

4. Sebagian besar (75\%) widyaiswara memiliki kompetensi professional Baik dan sisanya (25\%) justru memiliki kompetensi professional yang Baik Sekali

5. Sebagian besar (75\%) guru peserta Diklat PKG memiliki tingkat prestasi belajar Baik dan hanya sebagian kecil saja (25\%) yang memiliki tingkat prestasi belajar yang Baik Sekali.

6. Sebagian besar guru peserta diklat PLPG telah mendapatkan Sertifikasi Kompetensi Keahlian Ganda sebagai bukti kelulusannya. 


\section{BIBLIOGRAFI}

Ananda, Arif Firdausi, Mukhadis, Amat, \& Andoko, Andoko. (2012). Kinerja Guru Kejuruan Bersertifikat Pendidik ditinjau dari Standar Kompetensi Guru Profesional sesuai Undang-Undang Nomor 14 Tahun 2005. Teknologi Dan Kejuruan, 33(1).

Anggara, Anggi. (2017). Pengaruh Komunikasi Dan Kompetensi Profesional Terhadap Mutu Layanan Pembelajaran Penjaskes. Syntax Literate; Jurnal Ilmiah Indonesia, 2(1), 21-32.

Hadian, Dedi, \& Yulianti, Irma. (2011). Pengaruh Kompetensi Guru Pembimbing, Iklim Organisasi, Dan Kepemimpinan Kepala Sekolah Terhadap Kinerja Guru Pembimbing Pada SMA Se-Kota Cimahi. Jurnal Ekonomi, Bisnis \& Entrepreneurship, 5(2), 63-73.

Jubaedah, Yoyoh. (2012). Competency Based Assessment Sebagai Model Pengujian Kompetensi di SMK. Prosiding Aptekindo, 6(1).

Nugraha, Teguh. (2014). Pengaruh Kompetensi Pengelolaan Pembelajaran Widyaiswara Terhadap Mutu Layanan Pembelajaran di Pusdiklat Geologi. Universitas Pendidikan Indonesia.

Ratnata, I. W., Saputra, W. S., Somantri, M., Mulyana, E., \& Ardhika, A. (2018). Preliminary Study of Micro-hydro Power Plant (MHPP) in The Rural Area. IOP Conference Series: Materials Science and Engineering, 384(1), 12067. IOP Publishing.

Redaksi, Pengantar. (n.d.). The 8th Indogreen Environment \& Forestry Expo 2016.

Rizkiyah, Nurul Farikhatir, Mariana, Rina Rifqie, \& Soekopitojo, Soenar. (2018). Sertifikasi Asesor Kompetensi Guru Produktif Program Keahlian Tata Boga dalam Pelaksanaan Uji Sertifikasi Kompetensi. Jurnal Pendidikan: Teori, Penelitian, Dan Pengembangan, 3(6), 708-714.

Trianto, S. Pd, \& Pd, M. (2007). Model-model pembelajaran inovatif berorientasi Konstruktivistik. Jakarta: Prestasi Pustaka.

Triastuty, Diana, Purnama, I. Ketut Eddy, \& Sumpeno, Surya. (n.d.). Clustering Untuk Data Kompetensi Widyaiswara Menggunakan Algoritma Kmeans.

Warisdiono, Eko, Gani, Darwis S., \& Susanto, Djoko. (2013). Kompetensi Fasilitator Pelatihan Pusat Pengembangan dan Pemberdayaan, Pendidik dan Tenaga Kependidikan Pertanian (P4TK Pertanian) Kementerian Pendidikan dan Kebudayaan. Jurnal Penyuluhan, 9(2).

Yasri, Indra, bin Hamid, Nor Hisham, \& Yap, Voon Vooi. (2009). An FPGA implementation of gradient based edge detection algorithm design. 2009 International Conference on Computer Technology and Development, 2, 165-169. IEEE. 